\title{
Investment Impact of Microfinance Credit in Ghana
}

\author{
Frederick Murdoch Quaye ${ }^{1} \&$ Valentina Hartarska ${ }^{2}$ \\ ${ }^{1}$ College of Business, Albany State University, Albany, GA, USA \\ ${ }^{2}$ Auburn University, Auburn, AL, USA \\ Correspondence: Frederick Murdoch Quaye, College of Business, Albany State University, Albany, GA, USA. \\ Tel: 1-229-430-4771. E-mail: frederick.quaye@ asurams.edu
}

Received: December 22, 2015

Accepted: January 28, $2016 \quad$ Online Published: February 25, 2016

doi:10.5539/ijef.v8n3p137

URL: http://dx.doi.org/10.5539/ijef.v8n3p137

\begin{abstract}
This research paper examines the impact of the microfinance sector on small/micro enterprises in Ghana. The study uses 2007 BEEPS data and employs the financing constraints approach used by several other researchers in the study area to study if the presence of microfinance institutions has been successful in alleviating financing constraints associated with small enterprises. This is done by comparing investment sensitivity to internally generated funds (cash flow) in enterprises with and without access to microfinance institutions. The study also uses a Propensity Score Matching method to reinforce/support the results obtained from the financing constraints approach. The results obtained from the analyses indicate that small/micro enterprises in areas with adequate MFIs have investment less sensitive to the availability of internal funds due to the fact that they have better access to external funds. This result thus shows that the microfinance sector is alleviating financing constraints in the country.
\end{abstract}

Keywords: microfinance, financing constraints, cash flow sensitivity, investment, internal funds

\section{Introduction}

Evaluation of the impact of microfinance on expansion of small businesses in Ghana is important because the country has high expectations about the ability of microfinance to promoting growth. Like many other countries in Africa, Ghana recognizes the importance that small enterprises place on the economy. Indeed previous literature argues that small enterprises are very important for economic growth (Hartarska et al., 2006; Berkowitz et al., 2002; McMillan et al., 2002).

Microfinance primarily involves the provision of financial services including savings, micro-credit, micro insurance, micro leasing and transfers in relatively small transactions by microfinance institutions (MFIs) designed to be accessible to micro-enterprises and low-income households that lack access to banking and related services due to the high transaction costs associated with serving these client categories. Microfinance is seen as a critical financial tool to enhance the ability of the poor to overcoming poverty, and hence could play a key role in the development of a country such as Ghana. Asiama (2007) lists the key effects microfinance plays as helping very poor households meet certain basic needs and protect them against risks, improving household economic welfare and helping to empower women by supporting women's economic participation. Otero (1999) also notes that microfinance creates access to productive capital for the poor, which together with human capital, addressed through education and training, and social capital, achieved through local organization building, enables people to move out of poverty.

This paper studies the investment impact of MFIs on small/ micro enterprises in Ghana but unlike other studies has a countrywide focus. Previous microfinance research in Ghana has focused on topics such as identifying the factors which affect the operations of MFIs, regulations governing the sector, and challenges that the sector continues to face. The few impact studies focus either on evaluating a specific microfinance institution, or on a particular geographic area. The focus of this paper is to determine whether the operations of the MFIs in Ghana as a whole have impacted enterprises positively in investment terms. The paper employs the financing constraints approach to evaluate the impact of microfinance through investment in Ghana. As stated by Hartarska et al. (2008), this methodological approach avoids the typical challenges associated with impact assessment studies where MFI clients serve as a treatment group with other individuals or enterprises that are not clients serving as a control group. The effectiveness of the MFIs in the country is judged by the sensitivity of small/ 
micro enterprises' investment to availability of internal funds. Other studies which employed this approach include Budina et al. (2000) and Hartarska et al. (2006). The paper further uses a Propensity Score Matching procedure in determining the effect of credit access on investment.

An overview of the microfinance sector in Ghana and review of the relevant literature is discussed in the next section. The analytical framework and empirical model used for the analysis are then presented in the third section. Afterwards the data and estimation procedures are described in the fourth section followed by the empirical results and the subsequent discussion of the estimation. The paper ends with some concluding remarks which might be very helpful for policy implications.

\section{An Overview of the Relevant Literature}

Microfinance type services are not new in Ghana and date back to the colonial era. Asiama (2007) writes that the first credit union in Africa was established in Northern Ghana in 1955 by Canadian Catholic missionaries. Over the years, the microfinance sector has thrived and developed into a well-organized and nationally coordinated commercial sector in the country regardless the numerous challenges it has faced and this has been made possible by the various financial sector policies and programs undertaken by different governments since independence (Gallardo et al., 2005). Among these are the provision of subsidized credits in the 1950s, the establishment of the Agricultural Development Bank in 1965 specifically to address the financial needs of the fisheries and agricultural sector, the establishment of Rural and Community Banks (RCBs) and the introduction of regulations such as commercial banks being required to set aside $20 \%$ of total portfolio to promote lending to agriculture and small scale industries in the early 1980s, among some few others (Steel et al., 2003). Problems that the microfinance sector has faced over the years include very high interest rates, information asymmetry and lack of access to credit by the MFIs themselves.

Microfinance in Ghana can be categorized into three main groups (Asiama, 2007). These are formal suppliers such as savings and loans companies, rural and community banks, as well as some development and commercial banks, semi-formal suppliers such as credit unions, financial non-governmental organizations (FNGOs), and cooperatives and lastly informal suppliers such as susu (Note 1) collectors and clubs, rotating and accumulating savings and credit associations (ROSCAs and ASCAs), traders, moneylenders and other individuals. The Bank of Ghana (BoG) which is the central bank oversees all the operations of MFIs in the country. The government observes that the overall policy framework for microfinance is informed by the poverty reduction strategy, which seeks to balance growth and macroeconomic stability with human development and empowerment in such a way as to positively impact the reduction of the country's poverty levels in the medium term (Government of Ghana, 2005).

There exist over 300 formal MFIs and an unspecified higher expected number of informal MFIs operating across the length and breadth of the country (Kyereboah-Coleman, 2007). Among these figures, 90 institutions are registered with the Ghana Microfinance Institutions Network (GHAMFIN (Note 2)) and serve over 500,000 clients across the country (from MFT data). The main activities of these institutions are savings, micro-credit delivery and financial consulting for individuals and small enterprises. Currently working in partnership with GHAMFIN, Association of Rural Banks (ARB), Association of Non-Governmental Organizations (ASSFIN), Credit Union Association of Ghana (CUA) and Ghana Co-operative of Susu Collectors Association (GCSCA), 33 of these institutions submit their microloan product information and pricing data to a national private US-based non-profit organization known as the Microfinance Transparency (MFT) in order to promote transparency and client protection through the Transparent Pricing Initiative in Ghana.

As stated earlier, previous research on microfinance focused on factors affecting the operations of MFIs, regulations governing the sector, challenges that the sector faces and impact analyses of the MFIs but with the impact analyses focusing on specific geographic areas and specific MFIs. For instance, Anim (2009) studied the sensitivity of loan size to lending rates in the and found out that there exist pronounced variations in the responsiveness of loan size to interest rate changes at different percentiles in the country. Gallardo (2001) studied the framework for Regulating MFIs in Ghana and the Philippines and structured out the similarities and differences that exist between the sectors of the two economies. His paper primarily sought to provide a framework for addressing regulatory issues which impact the operations and the institutional development of MFIs. Gallardo et al. (2005) also worked on the comparative review of microfinance regulatory framework issues in Benin, Ghana and Tanzania also with the objective of suggesting how the sector must be regulated.

Basu et al. (2004) estimated that in Ghana only about 6 percent of the entire population has access to formal financial services, with the majority applicants denied credit and these individuals and enterprises therefore tend to rely largely on informal sources such as friends, relatives, suppliers and money lenders for their financial 
needs. Provision of loans to individuals and small enterprises has been found as a great remedy in reducing or alleviating poverty, particularly when used judiciously to generate some form of a long-term source of income. In this light, Adjei et al. (2009) confirms that the provision of financial services to individuals or households helps them to better manage their existing asset base and reduce liabilities. Access to loans, they claim, provides a security and a fallback position if difficulties are encountered.

The impact analyses of MFIs in Ghana include studies by Nanor (2008), Afrani (1997), Onyina et al. (2011), Gyamfi (2011) and Adams et al. (2010). Nanor (2008) studied the impact of microfinance on selected districts in the Eastern region of Ghana. Focusing on four districts and basing his sample on household units, the results of the study indicated that microfinance had positive impact on the household income of the respondents from two districts whilst there was no impact on the household income for the other two districts. Afrani (1997) undertook an impact study of the operations of Sinapi Aba Trust (Note 3) (SAT) as a contribution to an International Transformation Research carried out by the OI Research Group. His work sought to assess the nature and degree of changes that clients have experienced in their businesses since they started benefiting from the credit scheme of SAT, and to further examine the extent to which these changes in their businesses have affected other aspects of their lives. The results of the study showed that an improvement in the conditions of the clients occurred following the receipt of credit. Similar to Afrani's study, Onyina et al. (2011) also performed an assessment of the impact of microfinance on clients who received loans from the Sinapi Aba Trust of Ghana. With a more detailed analysis, the results show that old clients are more likely to acquire assets, improve their businesses, and spend larger amounts on their children's education than new clients. Gyamfi (2011) performed a case study of the First Allied Savings and Loans Limited (FASLL) with the aim of analyzing the impact of microfinance on poverty reduction for the company's clients. With a random sample of small/micro enterprises drawn from different districts, the study revealed that despite two main problems faced by FASLL (payment default and inadequate capital to sustain and cater for the growing number of clients), the company has been successful in improving the economic livelihood of the respondents. Adams et al. (2010) analyzed the impact of microfinance on maize farmers in the Brong-Ahafo region with their results showing positive impacts of microfinance on both the social and economic well beings of the clients.

In another interesting study, Kyereboah-Coleman (2007) examined the impact of capital structure on the performance of MFIs. Using a 10-year period panel data with both fixed and random effect techniques, the study finds that most examined MFIs employ high leverage and finance their operations with long term debt. The results also indicated that highly leveraged MFIs perform better by reaching out to more clientele, enjoy scale economies and are better able to deal with moral hazard and adverse selection, thus enhancing their ability to deal appropriately with risk. Just recently, Alhassan et al. (2013) assessed the impact of MFI's institutional capacity on advocacy for women empowerment in the Northern region. They mainly observed that MFIs covered in their study were short on plausible advocacy strategies capable of influencing policy reforms that can endanger women empowerment. They also observed that the employees of these MFIs lack the requisite advocacy skills and there are no short or long term strategies put in place to equip employees with the necessary expertise.

Several studies have clearly pointed out the importance and positive effects associated with microfinance in alleviating poverty. However, various studies have likewise questioned these positive impacts across regional boundaries and suggests from theory that microfinance works differently in different regions due to variations in population density, attitudes to debt, group-cohesion, enterprise development, financial literacy and financial services provision (Rooyen et al., 2012). This is because some studies have indicated much more mixed impacts, whilst other studies have also identified certain flaws and drawbacks associated with this developmental tool. Such negative instances could be seen in countries where microfinance institutions have recorded high default rates with thousands of poor entrepreneurs being over-indebted.

Rooyen et al.s (2012) systematic review of the microfinance impact literature in Sub-Saharan Africa identifies two main findings based on quality, relevant and reliable microfinance impact studies in the sub-region. The first issue is what the impact on financial outcomes was. The overview shows that microfinance has had both positive and negative impacts on the incomes of poor people, whilst in some instances there are no impacts at all. It is observed that microfinance clientele tend to invest more but it is uncertain whether these additional investments lead to greater profit levels. In addition, they observe that microfinance services increase both expenditure and the accumulation of assets. It is worth-noting though that while these businesses initially accumulate more assets, this asset accumulation reduces and stops over time. The second issue is the impacts on non-financial outcomes. Evidence suggests that microfinance generally have a positive impact on the health of poor entrepreneurs and this is comparatively observed based mainly on the number of days they are unable to work due to sickness. 
Majority of the evidence also suggests that microfinance has a positive impact on food security and nutrition, but this is not the same across all regions. Evidence on the impact on both education and women's empowerment suggest both positive and negative impacts whilst impact on housing generally has positive results. There is however very little evidence that suggests a positive impact on job creation whilst there is no evidence concerning the impacts on child labor and social cohesion.

Our approach is a modification of that proposed by Hartarska and Nadolnyak (2008) who studied the impact of microfinance on microenterprises in Bosnia and later applied in a region-wide study of impact of microfinance in Eastern Europe and Central Asia (McAdams, Hartarska, \& Nadolnyak 2013). This method is relevant to study impact of microfinance on microenterprises in Africa as shown by Abiola (2011) who apply it to Nigeria (Note 4). The similarities between the sectors in Nigeria and Ghana-two West-African neighbors-suggest that such an approach can be used to the Ghanaian system.

\section{Analytical Framework and Empirical Model}

An impact study typically starts by defining what impact will be measured and what variable will be used to evaluate the improvement. The benefits from microfinance are argued to be both economic and social terms. While the literature review showed that at the impact on various social aspects of selected MFIs in Ghana has been studies, no work has evaluated the impact of the overall microfinance sector on microfinance sectors' ability to promote economic growth, or in other words on the growth of the microfinance enterprise themselves. While there is variation in the stated social objectives of various MFIs, all MFIs state that they lend to improve the economic opportunities to their clients. One of the biggest concerns of potential entrepreneurs around the world is inability to access funds. Alleviating these financing constraints for would-be entrepreneurs is a crucial goal for policy makers worldwide (Kerr et al., 2010). We want to find out if MFIs in Ghana improve access to microloans and alleviate financing constraints, and thus find out if they promote microentrepreneurship.

The financing constraint method to evaluate microfinance impact proposed by Hartarska and Nadolnyak 2008 is based on the liquidity constraints empirical application dating back to Fazary et al. (1988). The basic argument is that since financing constraints do not affect all firms/ enterprises uniformly, the extent of effective financing constraints that different enterprises face provides information on the ability of the financial system to cater for these firms' financial needs. Investment in microenterprises with limited or no access to credit markets (due to the absence of or poor functioning of credit markets) is therefore more dependent on internal funds than is investment in microenterprises with better functioning credit markets. This is translated in empirically testing for differences in the sensitivity of investment to internal funds in enterprises with different levels of informational opacity by splitting a sample of enterprises into sub-samples defined according to theoretical priors that characterize constrained and unconstrained enterprises. Hartarska and Nadolnyak (2008) propose as an external prior the availability of MFIs in reasonable area where the microenterprise operates. Thus, if investment in enterprises in areas with MFIs is less sensitive to internally generated funds relative to investment in microenterprise without MFIs, then it can be argued that MFIs alleviate financing constraints and thus have a positive impact on the economy. This approach estimates a reduced-form investment equation for each sub-sample (with access and without access) where investment is modeled as a function of the enterprise's internal funds, investment opportunity and controls.

While the empirical discussion and applications of the financing constraints approach is not new and has been subjects to discussion, part of its theoretical justification come from a more recent literature (Note 5). Cleary, Povel and Raith (2007) shows that for positive or slightly negative levels of enterprise wealth, investment is positively related to internal finance. These are also done for the control group and a statistically significant difference in the investment sensitivity to internal funds across the sub-samples signifies a group being more credit constrained than the other.

In this study we modify the Hartarska and Nadolnyak (2008) and Abiola (2011) approach but use self identifies access to microcredit as a sample split criteria. Moreover, since it is important to define properly the access and non-access (control group) groups, we go a step further. SO in addition to following Hartarska and Nadolnyak (2008) we do a robustness check where we use propensity score matching to select the groups with and without access and estimate the treatment impact on investment.

We start by estimating the reduced investment equation with a Tobit model typically used when the dependent variable is censored (investment cannot be less than zero as disinvestment was not recorded by the data). For data clustered at a limiting value, usually zero, the Tobit technique gives best results since it uses all observations both those at the limit and those above the limit (McDonald et al., 1980). The survey question does not allow respondents to record negative investments and some microenterprises record investment of zero even though 
they might have negative investment.

The Tobit model in this case is formulated as;

$$
I n v=\left\{\begin{array} { l } 
{ X _ { t } \beta + u _ { t } } \\
{ 0 }
\end{array} \text { if } \left\{\begin{array}{l}
X_{t} \beta+u_{t}>0 \\
X_{t} \beta+u_{t} \leq 0
\end{array} \text { for } t=1,2, \ldots, \mathrm{N}\right.\right.
$$

where $\mathrm{N}$ represents the number of observations and $\operatorname{Inv}$ i.e. the dependent variable represents the amount of investment made during the previous year. $X$ represents a vector of independent variables, $\beta$ is a vector of unknown coefficients whilst $\varepsilon$ is an independently distributed error term assumed to be normal with zero mean and constant variance.

The model is estimate for two subgroups (with and without credit access), following the financing constraints approach namely:

$$
\operatorname{Inv}=\beta_{0}+\beta_{1} I F+\beta_{2} I O+\beta_{3-8} Z
$$

where Inv is investment, IF is internal funds variable (Cash flow), IO is investment opportunity variabl, and $\mathrm{Z}=$ a vector of variables that capture various characteristics of the enterprise. In the reduced form equation, we have both internal funds and investment opportunity because enterprises without investment opportunities would not invest even if they had capital. Since the investment is in microenterpsies various control variables are also included.

The variables used are similar to those in Hartarska and Nadolnyak (2008) and Abiola (2011). The dependent variable is investment in fixed assets in the year prior to the survey. The cash flow variable measures the available internal funds. Investment opportunity is assumed to be measured by enterprises hiring part-time workers as they foresee opportunities and thus part-time worker hiring would be used as a proxy for investment opportunity. As in Abiola (2011) a dummy variable measuring whether enterprises hired part-time workers during the previous year measures investment opportunities whereas enterprises with no such hires, (with industry controls for possible industry variations) are assumed to have no investment opportunities.

We formulate the hypothesis to be tested as

$\mathrm{H}_{0}$ : $\beta_{1}$ does not differ across the two groups. That is, investment in micro enterprises with access to microfinance (with MFIs present on the market) is as sensitive to the availability of internal funds as is investment in microenterprise without access.

Unlike previous works, we add a Propensity Score Matching (PSM) method to match enterprises according to their covariate propensity scores based on access to credit. This helps to determine the effect of microcredit access on the small/ micro enterprises with the counterfactual being that what would have happened to the unconstrained group if they actually had no access to credit like the control group. This procedure (PSM) also helps eliminate some of the possible supply side selection bias.

The investment choice (i.e. the amount of investment made in the previous year) as the 'outcome variable' is justified since it obeys the Conditional Independence Assumption (CIA), which assumes that given a set of observable covariates $X$, which are not affected by treatment, the potential outcome(s) should be independent of treatment assignment i.e. $Y(0), Y(1) \amalg D \mid X$ where $Y(0)$ and $Y(1)$ are the outcomes for the treatment and control groups respectively.

Given that CIA holds and assuming additionally that there is an overlap between both groups (as was suggested by Heckman et al., 1998), the propensity score matching estimator for the 'average treatment for the treated' (ATT) as was formulated by Caliendo et al. (2005) can be written as:

$$
{ }^{\tau} A T T=E_{P(X) \mid D=1}\{E[Y(1) D=1, P(X)]-E[Y(0) D=0, P(X)]\}
$$

We use the Mahalanobis metric matching procedure due to its preferred properties (Sianesi, 2001).

\section{Data}

Cross-sectional data microenterprises were obtained from the Ghana Business Environment and Enterprise 
Performance Survey which is part of the Business Environment and Enterprise Performance Survey (BEEPS) series of the World Bank for the year 2007. The survey was conducted by the Ghana Statistical Service, the public institution authorized by the government with sole responsibility of conducting national statistical surveys and population and housing surveys. The data consist of enterprises from the Production (Manufacturing), Service and Trade sectors and thus the sampling reduction bias issues raised by Carreira et al. (2010) are not relevant here. This makes the financing constraint approach appropriate for this data without generating such bias. Use of cross-sectional data to evaluate the impact of microfinance and of finance in various countries is not unusual (e.g. Deloach et al., 2011; Abiola, 2011; Hartarska et al., 2008; and Devi et al., 2011). The questionnaire has a section which asks detailed questions on individual or group enterprises including their business activities over the previous year. The data also contain information about enterprises' use of microfinance and the metropolises where the enterprises are located.

We focus our analysis on enterprises with less than 20 permanent employees (Note 6). This includes micro enterprises (enterprises with less than 5 employees) and very small enterprises (with 5-19 employees). We classify the entrepreneurs as financially unconstrained or constrained based on the their self-acknowledgement, a procedure referred to as 'direct elicitation' used in studies such as Quisumbing (2006) and Simtowe et al. (2006). Enterprises that acknowledge access to finance is either a little a no obstacle are classified as unconstrained whilst enterprises that say access as either a moderate, major or a very severe obstacle are classified as constrained. We only use data from enterprises that had previously received credit from an MFI (Note 7).

Several observations (how many) of constrained enterprises that had received credit only from banks are not dropped because small/micro enterprises admitting that access to finance is a constraint should technically be eligible and have access to microfinance loans which in most cases overlaps with the operations of some banks. Further, 2 unconstrained enterprises were dropped for consistency although they have not received credit from MFIs perhaps because they do not have constraints or because they used bank loans but these 2 observations do not change the final result. Most of the enterprises that have taken credit form MFIs have also at a point in time taken credit from banks.

The final sample of 489 enterprises operating in the Accra, Tema, Takoradi, Kumasi and Tamale metropolises is used for the estimation. This comprises of 100 unconstrained observations (representing 20.45\% of the sample) and 389 constrained observations (representing $79.55 \%$ of the sample). The variable measuring cash flow is obtained by subtracting total costs from total sales for the year 2006. A positive relationship is therefore expected between cash flow (internally generated funds) and investment. Investment opportunity as stated earlier is estimated using 2006 part-time worker hiring as a proxy.

Table 1 presents the summary statistics of the variables used in the analysis. These are grouped into two in terms of whether enterprises are constrained or unconstrained with respect to access to microcredit from MFIs. The entire sample comprising both constrained and unconstrained enterprises is also summarized alongside the individual groups. Continuous variables have mean values whilst dummy variables are summarized by their percentages. In addition, standard errors for continuous variables and proportions for the categorical variables are presented in parentheses. The a priori expectations are stated based on hypotheses consistent with previous findings and the theory.

The summary statistics of the two groups show that the data conform to theory to a good extent. The data show that unconstrained enterprises averagely invested higher amounts into their fixed assets compared to the constrained ones. More so, the unconstrained enterprises had averagely higher amounts of cash flow than constrained enterprises. It is observed that over fifty percent of unconstrained enterprises for both groups are females whilst over forty-five percent of constrained enterprises are females with an average for the entire sample being $47.9 \%$. This shows that small/ micro enterprise owners are almost evenly represented in terms of gender indicating that enterprises could be run by both sexes so far as they have the required skills and know-how. In addition, Table 1 shows that majority of the enterprises are mainly into production whilst the least proportion are in the service sector i.e. more than forty percent of total sample are in the production sector. Unconstrained enterprises also do have averagely more number of permanent workers than do constrained enterprises with a ratio of about seven to six. 
Table 1. Summary statistics

\begin{tabular}{|c|c|c|c|c|c|c|}
\hline Variable & Description & Measurement & Total Sample & Unconstrained & Constrained & Apriori Sign \\
\hline Inv & $\begin{array}{l}\text { Amount of investment } \\
\text { made in previous year }\end{array}$ & Continuous (GHC1000) & $2.04(8.44)$ & $3.41 *(15.57)$ & $1.64 *(5.22)$ & \\
\hline Cash flow & $\begin{array}{l}\text { Total revenue less } \\
\text { total costs }\end{array}$ & Continuous (GHC1000) & $23.71(124.19)$ & $56.74^{* * *}(240.48)$ & $7.04^{* * *}(50.30)$ & + \\
\hline Invoppor & $\begin{array}{l}\text { Investment } \\
\text { Opportunity }\end{array}$ & $\begin{array}{c}\text { Dummy ( } 1 \text { if enterprise hired } \\
\text { part-time worker, } 0 \\
\text { otherwise) }\end{array}$ & $18.94 \%(93)$ & $15 \%(15)$ & $20.1 \%(78)$ & + \\
\hline permemploy & $\begin{array}{c}\text { Permanent number of } \\
\text { employees }\end{array}$ & Continuous & $6.82(4.15)$ & $7.21(4.49)$ & $6.74(4.07)$ & + \\
\hline Entage & Enterprise Age & Continuous (Years) & $11.15(8.63)$ & $10.54(8.33)$ & $11.33(8.72)$ & + \\
\hline Manufac & Manufacturing Sector & $\begin{array}{c}\text { Dummy ( } 1 \text { if manufacturing } \\
\text { enterprise, } 0 \text { otherwise) }\end{array}$ & $41.75 \%(205)$ & $34 \% *(34)$ & $44.0 \% *(171)$ & $+/-$ \\
\hline Trade & Trade Sector & $\begin{array}{c}\text { Dummy ( } 1 \text { if trade enterprise, } \\
0 \text { otherwise) }\end{array}$ & $33.6 \%(165)$ & $36 \%(36)$ & $32.7 \%(127)$ & $+/-$ \\
\hline Service & Service Sector & $\begin{array}{c}\text { Dummy ( } 1 \text { if service } \\
\text { enterprise, } 0 \text { otherwise) }\end{array}$ & $24.64 \%(121)$ & $30 \%(30)$ & $23.4 \%(91)$ & $+/-$ \\
\hline Education & $\begin{array}{c}\text { Years of Formal } \\
\text { Education }\end{array}$ & Continuous & $4.44(1.63)$ & $4.76^{* *}(1.44)$ & $4.35^{* *}(1.67)$ & + \\
\hline Female & Female & $\begin{array}{l}\text { Dummy variable ( } 1 \text { if female, } \\
0 \text { otherwise) }\end{array}$ & $47.86 \%(234)$ & $52 \%(52)$ & $46.8 \%(182)$ & $+/-$ \\
\hline $\begin{array}{c}\text { Working } \\
\text { hours/week }\end{array}$ & $\begin{array}{l}\text { Number of Hours } \\
\text { worked per week }\end{array}$ & Continuous & $51.92(17.0)$ & $57.56(12.02)$ & $63.65(13.33)$ & + \\
\hline Generator Usage & $\begin{array}{c}\text { Generator usage } \\
\text { during power outage }\end{array}$ & $\begin{array}{c}\text { Dummy ( } 1 \text { if enterprise owns } \\
\text { a working generator, } 0 \\
\text { otherwise) }\end{array}$ & $7.33 \%(35)$ & $13 \%(13)$ & $5.66 \%(22)$ & + \\
\hline
\end{tabular}

Parentheses have standard errors for continuous variables and proportions for dummy variables.

$* * *, * *, *$ implies statistically significant mean differences at the $1 \%, 5 \%$ and $10 \%$ levels respectively.

The data however deviate from theory in terms of enterprise's age since the recorded enterprise age averages for unconstrained enterprises are lesser than those of the constrained enterprises. This is because it is expected from theory that older enterprises would have much access to finance since potential lenders are more able to observe the amount of the risk associated with the investment of older enterprises than that of younger enterprises. This deviation may have been caused by the establishment of MFIs much farther away from older enterprises than from younger enterprises, a situation which would probably not have been deliberate. In addition, the average number of years of formal education for unconstrained enterprise owners is slightly higher than that of constrained enterprise owners though the difference is not much. This could be attributed to the fact that much better educated enterprise owners are able to use their knowledge to strategically position themselves in securing funds more as compared to their less educated compatriots. It can however be seen from the summary that education is a problem among the entrepreneurs with a total sample average value of about 4.4 years of formal education.

\section{Results and Discussion}

Table 2 presents the Tobit regressions by group of the unconstrained and constrained micro/ small enterprises. The Tobit function in Stata by default reports the coefficients which are the marginal effects on the latent dependent variable (Newton et al., 2000). Its marginal effect function reports four different forms of marginal effects at the means of the independent variables. These include the $\beta$ coefficients themselves which are the changes in the mean of the latent dependent variable, the changes in the unconditional expected value of the observed dependent variable, the changes in the conditional expected value of the dependent variable and the changes in the probability of being uncensored. All four marginal effects for both unconstrained and constrained enterprises are reported in the appendix (Tables 5 and 6). In addition to the regression results presented in Table 2 , the sample consisting of enterprises with credit from banks only is also analyzed and the results presented in the fourth and fifth columns. This is a robust check to determine if dropping such observations had significant implications on the results. As expected, dropping such minute number of observations did not cause any significant changes in the results. It can be observed that columns 3 and 5 in Table 2 are the same since no constrained observation was dropped. 
As stated earlier, a statistically significant difference in investment-cash flow sensitivity between the two groups would indicate how efficient MFIs have been to small/ micro enterprises in Ghana. In conformance to the apriori expectation, the cash flow variable is positive and statistically significant for both constrained and unconstrained enterprises. As seen in Table 2, investment-cash flow sensitivity for unconstrained enterprises is 0.0195 as against 0.0317 for unconstrained enterprises. This shows that in the Ghanaian setting, constrained enterprises rely more on their internal funds (cash flow) than do unconstrained enterprises in accordance to the theoretical literature.

A t-test was conducted to determine if sensitivity difference between the two groups are statistically significant. The null hypothesis of equality between the two coefficients was rejected at the 5\% significance level indicating that unconstrained enterprises are indeed slower in using their internal funds for investment than constrained enterprises. With such results, statistical inferences could thus be made that MFIs in Ghana have alleviated financing constraints faced by small/ microenterprises to a good extent. The level of alleviation may not be very huge since many small enterprises still face challenges with funds, but the results show that they are in the process and with time, hopefully poverty could be alleviated to a very large extent, all things being equal.

Furthermore, the results for constrained enterprises show that as compared to enterprises without investment opportunities who did not hire part-time labour, those with investment opportunities are able to make an investment average of over six thousand Ghana cedis.

Table 2. Tobit regression by group for constrained and unconstrained enterprises

\begin{tabular}{|c|c|c|c|c|}
\hline Investment & Unconstrained & Constrained & Unconstrained (With Banks) & Constrained (With Banks) \\
\hline \multirow[t]{2}{*}{ Cash flow } & $0.0195^{*}$ & $0.0317 * * *$ & $0.0191^{*}$ & $0.0317 * * *$ \\
\hline & $(0.0112)$ & $(0.00789)$ & $(0.0107)$ & $(0.00789)$ \\
\hline \multirow[t]{2}{*}{ Inv Opportunity } & 8.133 & $6.433 * * *$ & 7.820 & $6.433 * * *$ \\
\hline & $(8.341)$ & $(1.143)$ & $(8.100)$ & $(1.143)$ \\
\hline \multirow[t]{2}{*}{ Entage } & $2.123 *$ & -0.0819 & $2.101 *$ & -0.0819 \\
\hline & (1.099) & $(0.181)$ & $(1.068)$ & $(0.181)$ \\
\hline \multirow[t]{2}{*}{$(\text { Entage })^{2}$} & $-0.0509^{*}$ & -0.00158 & $-0.0504^{*}$ & -0.00158 \\
\hline & $(0.0301)$ & $(0.00498)$ & $(0.0293)$ & $(0.00498)$ \\
\hline \multirow[t]{2}{*}{ Education } & 0.873 & 0.416 & 0.945 & 0.416 \\
\hline & $(2.971)$ & $(0.419)$ & $(2.852)$ & $(0.419)$ \\
\hline \multirow[t]{2}{*}{ Female } & 11.83 & -3.050 & 10.68 & -3.050 \\
\hline & $(22.59)$ & $(2.829)$ & $(21.52)$ & $(2.829)$ \\
\hline \multirow[t]{2}{*}{ Female*Educ } & -4.314 & 0.0638 & -4.068 & 0.0638 \\
\hline & $(4.651)$ & $(0.595)$ & $(4.427)$ & $(0.595)$ \\
\hline \multirow[t]{2}{*}{ Trade } & 6.184 & -0.176 & 5.626 & -0.176 \\
\hline & $(8.370)$ & $(1.235)$ & (7.898) & $(1.235)$ \\
\hline \multirow[t]{2}{*}{ Service } & 11.25 & 0.319 & 11.16 & 0.319 \\
\hline & $(8.100)$ & $(1.320)$ & (7.875) & $(1.320)$ \\
\hline \multirow[t]{2}{*}{ Permanent employees } & 0.719 & $0.423 * * *$ & 0.705 & $0.423 * * *$ \\
\hline & $(0.795)$ & $(0.130)$ & $(0.769)$ & $(0.130)$ \\
\hline \multirow[t]{2}{*}{ Working hours/week } & $0.699 * * *$ & $0.177 * * *$ & $0.648 * * *$ & $0.177 * * *$ \\
\hline & $(0.240)$ & $(0.0365)$ & $(0.199)$ & $(0.0365)$ \\
\hline \multirow[t]{2}{*}{ Generator Usage } & -14.75 & 1.275 & -13.96 & 1.275 \\
\hline & (10.07) & $(1.946)$ & $(9.357)$ & (1.946) \\
\hline \multirow[t]{2}{*}{ Constant } & $-77.22 * * *$ & $-18.31 * * *$ & $-73.76 * * *$ & $-18.31 * * *$ \\
\hline & $(24.16)$ & $(3.477)$ & $(21.40)$ & $(3.477)$ \\
\hline \multirow[t]{2}{*}{ _se } & $23.21 * * *$ & $7.630 * * *$ & $22.61 * * *$ & $7.630 * * *$ \\
\hline & $(2.643)$ & $(0.436)$ & $(2.508)$ & $(0.436)$ \\
\hline Observations & 100 & 389 & 102 & 389 \\
\hline Log Likelihood & -218.3 & -666.3 & -226.5 & -666.3 \\
\hline LR $\mathrm{Chi}^{2}$ & 25.27 & 116.99 & 26.76 & 116.99 \\
\hline Prob $>\mathrm{Chi}^{2}$ & 0.0136 & 0.000 & 0.0084 & 0.000 \\
\hline Pseudo $\mathrm{R}^{2}$ & 0.0747 & 0.1007 & 0.0758 & 0.1007 \\
\hline
\end{tabular}

Robust standard errors in parentheses.

$* * * \mathrm{p}<0.01, * * \mathrm{p}<0.05, * \mathrm{p}<0.1$ 
The results however show a statistically insignificant value for unconstrained enterprises. Also for constrained enterprises, the number of permanent employees that an enterprise has is very important and imperative in determining the amounts of investment made, this observed from the fact that an additional permanent employee increases investment by over four hundred Ghana cedis. Number of hours worked per week shows statistical significant results for both unconstrained and constrained enterprises with unconstrained enterprises having a higher magnitude. It is observed that an additional hour of work per week increases investment by over six hundred Ghana cedis for unconstrained enterprises whilst that of constrained enterprises increases by about one hundred and seventy Ghana cedis. The results also indicate that unconstrained enterprises invest more as their enterprises grow. An additional year of enterprise age of an unconstrained enterprise increases investment by over two thousand Ghana cedis. As expected, when the enterprise matures and exceeds a certain age, it starts to experience reduction in investment for every additional year, and this might be due to the economic theory of diminishing returns. Finally, it could be seen that the result in column 4 are very similar to those in column 2 indicating that the observations dropped did not cause any significant change in the results.

The Propensity Score Matching analyses are illustrated below. Table 3 presents the regression estimates whilst Table 4 presents the results for the Mahalanobis procedure.

The results show that the Average Treatment for the Treated (ATT) is about GH\$3,412 whilst that of the constrained group is about GHC 1,922 indicating a difference of about GHC 1490 between the amount of investments made by unconstrained and constrained small/ micro enterprises. This result show that even though unconstrained enterprises are less sensitive in terms of cash flow-investment sensitivity, they tend to make higher amounts of investment confirming the hypothesis that they acquire such funds from external sources due to their access to MFIs. An unequal variance t-test confirms that the difference is statistically significant.

As per the estimation results, the microfinance sector is seen to have positively impacted on enterprise performance as indicated in the literature and thus confirms the importance of MFIs in alleviating financing constraints for small enterprises as noted by studies such as Devi et al. (2011); Adjei et al. (2009); Abiola (2011) among others.

Table 3. Probit regression estimates for the propensity score matching analysis

\begin{tabular}{cc}
\hline Variables & Credit Access Variable (Constraint) \\
\hline Cash Flow & $0.0033^{* * *}$ \\
Investment opportunity & $(0.0009)$ \\
Enterprise Age & -0.2577 \\
& $(0.1645)$ \\
Education & -0.0051 \\
& $(0.0084)$ \\
Female & $0.0871^{* *}$ \\
& $(0.0449)$ \\
Permanent Employees & 0.1868 \\
Working hours/ week & $(0.1367)$ \\
Constant & 0.0123 \\
& $(0.0166)$ \\
Number of Obs & $0.0188^{* * *}$ \\
Log Likelihood & $(0.0048)$ \\
LR chi ${ }^{2}$ & $-0.2272^{* * *}$ \\
Prob > chi & $(0.3897)$ \\
Pseudo R ${ }^{2}$ & 489 \\
\hline
\end{tabular}

\footnotetext{
Standard errors in parentheses.
}

*** $\mathrm{p}<0.01, * * \mathrm{p}<0.05, * \mathrm{p}<0.1$. 
Table 4. Estimates for the mahalanobis matching procedure

\begin{tabular}{cccccc}
\hline Variable & Sample & Treated & Controls & Difference & S.E. \\
\hline Investment & Unmatched & 3.412 & 1.648 & 1.764 & 0.945 \\
& ATT & 3.412 & 1.922 & 1.490 & 1.694 \\
\hline
\end{tabular}

Treated $=100$

Untreated $($ Control $)=389$.

\section{Conclusion}

This paper uses the financing constraints approach to study the impact of microfinance on credit access for microenterprises in Ghana. A statistically significant difference in cash flow between unconstrained and constrained enterprises indicates how efficient MFIs have been to small/ micro enterprises in Ghana. From the financing constraints theory, a smaller magnitude of the cash flow variable for unconstrained enterprises indicates a lesser sensitivity to internal funds compared to constrained enterprises. The study uses a 2007 World Bank Enterprise data conducted by the Ghana Statistical Service (a cross-sectional survey data from five different metropolises namely the Accra, Tema, Kumasi, Takoradi and Tamale metropolises) in analyzing the sector. The Tobit regression procedure was used to assess the impact of microfinance on financially constrained and unconstrained enterprises by determining respondents' sensitivity to internal funds. Enterprises were classified either as unconstrained or constrained based on self-selection (direct elicitation). A Tobit model was used due to the censoring nature of the data in terms of investment (which is the independent variable) since many enterprises had a lower investment limit of zero.

The results recorded showed statistically significant cash flow estimates for both unconstrained and constrained enterprises. More so, unconstrained enterprises had a lower cash flow magnitude than that of constrained enterprises implying that investment sensitivity with regards to internal funds is indeed lesser for unconstrained enterprises. This shows that MFIs have to some extent alleviated financing constraints in the country even at a time when the sector was not very well established. The study further employs the Propensity Score Matching analysis to match farmers according to their covariate propensity scores based on access to credit. This helps to determine the effect of microcredit access on the small/ micro enterprises in terms of investment amounts made. With investment being the outcome variable, it was observed that unconstrained enterprises make higher amounts of investment (average treatment for the treated) compared to constrained enterprises indicating that even though unconstrained enterprises are less sensitive in terms of cash flow-investment sensitivity, they tend to make higher amounts of investment confirming the hypothesis that they acquire such funds from external sources due to their access to MFIs.

What needs to be done is for all stakeholders to join hands and resources to continue making the microfinance sector in Ghana one of the leading and big-league microfinance sectors in the African sub-region. One drawback of this study is that the 2007 BEEPS data used for the analysis does not provide information on household/ community income and does not also provide information on the specific locations and addresses of the enterprises. These variables have been used in some studies that classified firms/ enterprises as constrained or unconstrained using proximity of enterprises to MFIs. However, this does not affect this study since the self-selection procedure was used. Subsequent researchers with much integrated data might add more variables in estimating the impact of the MFI sector.

\section{References}

Abiola, B. (2011). Impact Analysis of Microfinance in Nigeria. International Journal of Economics and Finance, 3(4), 217-225. http://dx.doi.org/10.5539/ijef.v3n4p217

Adams, S., \& Bartholomew, T. A. (2010). The Impact of Microfinance on Maize Farmers in Nkoranza (Brong Ahafo Region of Ghana). Journal of Management Research, 2(2), E7. http://dx.doi.org/10.5296/jmr.v2i2.289

Adjei, J. K., Arun, T., \& Hossain, F. (2009). The Role of Microfinance in Asset-Building and Reduction: The Case of Sinapi Aba Trust of Ghana. BWPI Working Paper 87, Brooks World Poverty Institute, University of Manchester, UK.

Afrane, S. (1997). Transformation Research: An Assessment of the Impact of Micro Enterprises Financing on Clients of Sinapi Aba Trust, Kumasi. A report prepared for Sinapi Aba Trust-A Micro-Financing Agency in Ghana. 
Alhassan, B., \& Shani, B. (2013). Assessing the Impact of Effective Institutional Capacity on Advocacy for Microfinance Firms - A Case Study of Northern Ghana. International Business Research, 6(4), 101-113.

Allayannis, G., \& Mozumdar, A. (2004). The impact of negative cash flow and influential on investment-cash flow sensitivity estimates. Journal of Banking and Finance, 28(5), 901-930. http://dx.doi.org/10.1016/S0378-4266(03)00114-6

Almeida, H., \& Campello, M. (2001). Financial constraints and investment-cash flow sensitivities: New theoretical foundations. Working Papers, New York University.

Alti, A. (2003). How sensitive is investment to cash flow when financing is frictionless? Journal of Finance, 58(2), 707-722. http://dx.doi.org/10.1111/1540-6261.00542

Anim, S. K. (2009). Sensitivity of loan size to lending rates: Evidence from Ghana's microfinance sector. MPRA Working Paper No. 21280, University of Manchester, UK.

Asiama, J. P. (2007). Microfinance in Ghana: An Overview. Bank of Ghana Publication, Research Department Bank of Ghana.

Basu, A., Blavy, R., \&Yulek, M. (2004). Microfinance in Africa: Experience and lessons from selected African countries. IMF Working Paper WP/04/174, Washington, DC: International Monetary Fund.

Berkowitz, D., \& DeJong, D. N. (2002). Accounting for Growth in Post-Soviet Russia. Regional Science and Urban Economics, 32(2), 221-239. http://dx.doi.org/10.1016/S0166-0462(01)00077-1

Bottazzi, G., Secchi, A., \& Tamagni, F. (2010). Financial Constraints and Firm Dynamics. Discussion Papers 2010/99, Dipartimento di Scienze Economiche (DSE), University of Pisa, Pisa, Italy.

Budina, N., Garrestsen, H., \& De Jong, E. (2000). Liquidity constraints and investment in transition economies: The case of Bulgaria. Economics of Transition, 8, 453-475. http://dx.doi.org/10.1111/1468-0351.00051

Carreira, C., \& Silva, F. (2010). No Deep Pockets: Some Stylized Empirical Results on Firms' Financial $\begin{array}{llllll}\text { Constraints. Journal of } & \text { Economic }\end{array}$ http://dx.doi.org/10.1111/j.1467-6419.2009.00619.x

Cava La, G. (2005). Financial Constraints, the User Cost of Capital and Corporate Investment in Australia. Research Discussion Paper 2005-12, Reserve Bank of Australia.

Chaddad, F. R., \& Reuer, J. J. (2009). Investment dynamics and financial constraints in IPO firms. Strategic Entrepreneurial Journal, 3, 29-45. http://dx.doi.org/10.1002/sej.65

Cleary, W. S., Povel, P., \& Raith, M. (2007). The U-shaped investment curve: Theory and evidence. Journal of Financial and Quantitative Analysis, 42, 1-39. http://dx.doi.org/10.1017/S0022109000002179

Cummings, J. G., Hassett, K. A., \& Oliner, S. D. (2006). Investment behavior, observable expectations, and internal funds. American Economic Review, 96(3), 796-810. http://dx.doi.org/10.1257/aer.96.3.796

Deloach, S. B., \& Lamanna, E. (2011). Measuring the Impact of Microfinance on Child Health Outcomes in Indonesia. World Development, 39(10), 1808-1819. http://dx.doi.org/10.1016/j.worlddev.2011.04.009

Devi, K. S., Prabkar, C., \& Ponnarasi, T. (2011). Impact of Microfinance Innovation in Pushing back Rural Poverty in Tamil Nadu. Indian Journal of Agricultural Economics, 66(3), 429-443.

Erickson, T., \& Whited, T. M. (2000). Measurement error and the relationship between investment and $Q$. Journal of Political Economy, 108(5), 1027-1057. http://dx.doi.org/10.1086/317670

Gallardo, J. (2001). A Framework for Regulating Microfinance Institutions: The Experience in Ghana and the Philippines. The World Bank: Washington, DC.

Gallardo, J., Ouattara, K., Randhawa, B., \& Steel, W. F. (2005). Comparative Review of Microfinance Regulatory Framework Issues in Benin, Ghana and Tanzania. World Bank Policy Research Working Paper 3585, World Bank, Washington, D.C. http://dx.doi.org/10.1596/1813-9450-3585

Gomes, J. F. (2001). Financing investment. American Economic Review, 91(5), 1263-1285. http://dx.doi.org/10.1257/aer.91.5.1263

Government of Ghana. (2005). Growth and Poverty Reduction Strategy (GPRS II), 2006-2009: Policy Framework (Vol. 1). November. Accra, Ghana: Government of Ghana/NDPC.

Grossman, S. J., \& Hart, O. (1982). Corporate financial structure and managerial incentives. Chicago, IL.: University of Chicago Press. 
Gyamfi, M. O. (2011). The Impact of Microfinance on Poverty Reduction (A Case Study of First Allied Savings and Loans Limited). A Dissertation presented to the School of Economics and Business, Regent University College of Science and Technology, in partial fulfillment the requirement for the award of a Bachelor of Science degree in Banking and Finance. Accra, Ghana.

Harris, M., \& Raviv, A. (1990). Capital Structure and the informational role of debt. Journal of Finance, 45, 321-345. http://dx.doi.org/10.1111/j.1540-6261.1990.tb03693.x

Hartarska, V., \& Gonzalez-Vega, C. (2006). What Affects New and Established Firms' Expansion? Evidence from Small Firms in Russia. Small Business Economics, 27, 195-206. http://dx.doi.org/10.1007/s11187-006-0012-0

Hartarska, V., \& Nadolnyak, D. (2008). An impact of Microfinance in Bosnia and Herzegovina. World Development, 36(12), 2605-2619. http://dx.doi.org/10.1016/j.worlddev.2008.01.015

Hartarska, V., Nadolnyak, D., \& McAdams, T. (2012). Microfinance and Microenterprises' Financing Constraints in Eastern Europe and Central Asia. Microfinance in Developing: Issues, Policies and Performance Evaluation, pp. 22-35. Basingstoke, Hampshire, U.S.A. Palgrave Macmillan.

Jensen, M., \& Meckling, W. (1976). Theory of the firm: Managerial behavior, agency cost and ownership structure. Journal of Financial Economics, 43, 271-281. http://dx.doi.org/10.1016/0304-405x(76)90026-x

Kaplan, S. N., \& Zingales, L. (1997). Do investment-cash flow sensitivities provide useful measures of financing constraints. Quarterly Journal of Economics, 112(1), 169-215. http://dx.doi.org/10.1162/003355397555163

Kerr, W., \& Nanda, R. (2010). Financing Constraints and Entrepreneurship. NBER Working Paper 15498.

Kyereboah-Coleman, A. (2007). The impact of capital structure on the performance of microfinance institutions. The Journal of Risk Finance, 8(1), 56-71. http://dx.doi.org/10.1108/15265940710721082

Lyandres, E. (2007). Costly external financing, investment timing and investment-cash flow Sensitivity. Journal of Corporate Finance, 13(5), 959-980. http://dx.doi.org/10.1016/j.jcorpfin.2007.07.001

McDonald, J. F., \& Moffit, R. A. (1980). The Uses of Tobit Analyses. The Review of Economics and Statistics, 62(2), 318-321. http://dx.doi.org/10.2307/1924766

McMillan, J., \&Woodruff, C. (2002). The Central Role of Entrepreneurs in Economic Reform. Journal of Economic Perspectives, 16(3), 153-170. http://dx.doi.org/10.1257/089533002760278767

Modigliani, F., \& Miller, M. (1958). The cost of capital, corporate finance and the theory of investment. American Economic Review, 48, 261-97.

Morduch, J. (2000). The Microfinance 'shism'. World Development, 16, 429-466.

Nanor, M. A. (2008). Microfinance and its impact on selected districts in Eastern Region of Ghana. A Thesis submitted to the Department of Economics, Kwame Nkrumah University of Science and Technology in partial fulfillment of the requirements for the degree of Master of Philosophy. Kumasi, Ghana.

Newton, J., Cox, N., Garrett, J., Pagano, M., Royston, J., \& Ressie, J. (2000). Stata Technical Bulletin. STB-56, 27-34.

Onyina, P., \& Turnell, S. (2011). The Impacts of Microfinance Lending on Clients: Evidence from Ghana. Economics Department, Macquarie University, Sydney, Australia.

Otero, Ma. (1999). Binging Back Development in Microfinance. Journal of Microfinance, 1(1), 8-19.

Povel, P., \& Raith, M. (2002). Optimal investment under financial constraints: The roles of internal funds and asymmetric information. AFA 2002 Atlanta Meetings, Atlanta, GA.

Quisumbing, A. R. (2006). The long-term impact of credit constraints on assets, intergenerational transfers and consumption: Evidence from the rural Philippines. Unpublished manuscript, International Food Policy Research Institute, Washington, DC.

Rooyen, C. V., Stewart, R., \& De Wet, T. (2012). The Impact of Microfinance in Sub-Saharan Africa: A Systematic Review of the Evidence. World Development, 40(11), 2249-2262. http://dx.doi.org/10.1016/j.worlddev.2012.03.012

Simtowe, F., \& Zeller, M. (2006). The impact of access to credit on the adoption of hybrid maize in Malawi: An empirical test of an agricultural household model under credit failure. Munich Personal RePec Archive (MPRA) Paper No. 45. September. 
Steel, W., \& Andah, D. (2003). Rural and Microfinance Regulation in Ghana: Implications for Development and Performance of the Industry. Africa Region Working Paper Series No. 49.

Stiglitz, J., \& Weiss, A. (1981). Credit rationing in markets with imperfect information. American Economic Review, 71(3), 393-410.

\section{Appendix}

Table 5. Marginal effects $(\mathrm{dF} / \mathrm{dx})$ for unconstrained enterprises

\begin{tabular}{|c|c|c|c|c|}
\hline Variable & Latent Variable & Unconditional Expected Value & Conditional on being Uncensored & Probability Uncensored \\
\hline \multirow[t]{2}{*}{ Cash flow } & $0.0195 *$ & $0.0056^{*}$ & $0.0051^{*}$ & $0.0003 *$ \\
\hline & $(0.0112)$ & $(0.0033)$ & $(0.0029)$ & $(0.0002)$ \\
\hline \multirow[t]{2}{*}{ Invoppor $^{\#}$} & 8.133 & 2.7417 & 2.2930 & 0.1273 \\
\hline & $(8.341)$ & $(2.4425)$ & $(2.1791)$ & $(0.1236)$ \\
\hline \multirow[t]{2}{*}{ Entage } & $2.123^{*}$ & $0.6217 *$ & $0.5547^{*}$ & $0.0314^{*}$ \\
\hline & $(1.099)$ & $(0.3218)$ & $(0.2871)$ & $(0.0163)$ \\
\hline \multirow[t]{2}{*}{ Entage $^{2}$} & $-0.0509 *$ & $-0.0149 *$ & $-0.0133^{*}$ & $-0.0008 *$ \\
\hline & $(0.0301)$ & $(0.0088)$ & $(0.0078)$ & $(0.0004)$ \\
\hline \multirow[t]{2}{*}{ Education } & 0.873 & 0.2558 & 0.2281 & 0.0129 \\
\hline & $(2.971)$ & $(0.8699)$ & $(0.7761)$ & $(0.0440)$ \\
\hline \multirow[t]{2}{*}{ Female $^{\#}$} & 11.83 & 3.4474 & 3.0849 & 0.1730 \\
\hline & (22.59) & $(6.6143)$ & $(5.9009)$ & $(0.3346)$ \\
\hline \multirow[t]{2}{*}{ Female*Education } & -4.314 & -1.2631 & -1.1269 & -0.0639 \\
\hline & $(4.651)$ & $(1.3618)$ & (1.2150) & $(0.0689)$ \\
\hline \multirow[t]{2}{*}{ Trade $^{\#}$} & 6.184 & 1.8942 & 1.6543 & 0.0932 \\
\hline & $(8.370)$ & (2.4508) & (2.1866) & $(0.1240)$ \\
\hline \multirow[t]{2}{*}{ Service $^{\#}$} & 11.25 & 3.6982 & 3.1297 & 0.1736 \\
\hline & $(8.100)$ & (2.3718) & $(2.1160)$ & (0.1199) \\
\hline \multirow[t]{2}{*}{ Permemploy } & 0.719 & 0.2105 & 0.1825 & 0.0106 \\
\hline & $(0.795)$ & $(0.2328)$ & $(0.2077)$ & $(0.0118)$ \\
\hline \multirow[t]{2}{*}{ Working hours/week } & $0.699 * * *$ & $0.2046^{* * * *}$ & $0.1825^{* * *}$ & $0.0103^{* * *}$ \\
\hline & $(0.240)$ & $(0.0702)$ & $(0.0626)$ & $(0.0036)$ \\
\hline \multirow[t]{2}{*}{ Generator Usage $^{\#}$} & -14.75 & -3.2661 & -3.3674 & -0.1857 \\
\hline & (10.07) & (2.9490) & (2.6310) & $(0.1492)$ \\
\hline \multirow[t]{2}{*}{ Constant } & $-77.22 * * *$ & $-22.6129 * * *$ & $-20.1741^{* * *}$ & $-1.1439 * *$ \\
\hline & (24.16) & (7.0734) & (6.3106) & $(0.3578)$ \\
\hline
\end{tabular}

(\#) $\mathrm{dF} / \mathrm{dx}$ is for discrete change of dummy variable from 0 to 1.

Robust standard errors in parentheses.

$* * * \mathrm{p}<0.01, * * \mathrm{p}<0.05, * \mathrm{p}<0.1$.

Table 6. Marginal effects $(\mathrm{dF} / \mathrm{dx})$ for constrained enterprises

\begin{tabular}{|c|c|c|c|c|}
\hline Variable & Latent Variable & Unconditional Expected Value & Conditional on being Uncensored & Probability Uncensored \\
\hline \multirow[t]{2}{*}{ Cash flow } & $0.0317 * * *$ & $0.0103^{* * *}$ & $0.0088 * * *$ & $0.0015^{* * *}$ \\
\hline & $(0.00789)$ & $(0.0026)$ & $(0.0021)$ & $(0.0004)$ \\
\hline \multirow[t]{2}{*}{ Invoppor $^{\#}$} & $6.433 * * *$ & $2.7185^{* * *}$ & $2.0918 * * *$ & $0.3205^{* * *}$ \\
\hline & $(1.143)$ & $(0.3717)$ & $(0.3158)$ & $(0.0539)$ \\
\hline \multirow[t]{2}{*}{ Entage } & -0.0266 & -0.0266 & -0.0226 & -0.0039 \\
\hline & $(0.181)$ & $(0.0588)$ & $(0.0499)$ & $(0.0085)$ \\
\hline \multirow[t]{2}{*}{ Entage $^{2}$} & -0.00158 & -0.0005 & -0.0004 & -0.0001 \\
\hline & $(0.00498)$ & $(0.0016)$ & $(0.0014)$ & $(0.0002)$ \\
\hline \multirow[t]{2}{*}{ Education } & 0.416 & 0.1352 & 0.1148 & 0.0196 \\
\hline & $(0.419)$ & $(0.1363)$ & $(0.1158)$ & $(0.0198)$ \\
\hline \multirow[t]{2}{*}{ Female $^{\#}$} & -3.050 & -0.9807 & -0.8377 & -0.1423 \\
\hline & $(2.829)$ & $(0.9198)$ & $(0.7813)$ & $(0.1335)$ \\
\hline \multirow[t]{2}{*}{ Female*Education } & 0.0638 & 0.0207 & 0.0176 & 0.0030 \\
\hline & $(0.595)$ & $(0.1934)$ & $(0.1643)$ & $(0.0281)$ \\
\hline
\end{tabular}




\begin{tabular}{|c|c|c|c|c|}
\hline Trade $^{\#}$ & $\begin{array}{l}-0.176 \\
(1.235)\end{array}$ & $\begin{array}{l}-0.0569 \\
(0.4016)\end{array}$ & $\begin{array}{l}-0.0485 \\
(0.3412)\end{array}$ & $\begin{array}{l}-0.0083 \\
(0.0583)\end{array}$ \\
\hline Service $^{\#}$ & $\begin{array}{c}0.319 \\
(1.320)\end{array}$ & $\begin{array}{c}0.1050 \\
(0.4291)\end{array}$ & $\begin{array}{c}0.0887 \\
(0.3645)\end{array}$ & $\begin{array}{c}0.0151 \\
(0.0623)\end{array}$ \\
\hline Permemploy & $\begin{array}{c}0.423 * * * \\
(0.130)\end{array}$ & $\begin{array}{c}0.1374 * * * \\
(0.0423)\end{array}$ & $\begin{array}{c}0.1167 * * * \\
(0.0359)\end{array}$ & $\begin{array}{c}0.0199 * * * \\
(0.0061)\end{array}$ \\
\hline Working hours/ week & $\begin{array}{c}0.177^{* * *} \\
(0.0365)\end{array}$ & $\begin{array}{c}0.0576^{* * * *} \\
(0.0119)\end{array}$ & $\begin{array}{c}0.0489 * * * \\
(0.0101)\end{array}$ & $\begin{array}{c}0.0084 * * * \\
(0.0017)\end{array}$ \\
\hline 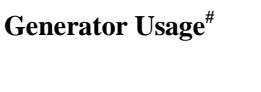 & $\begin{array}{c}1.275 \\
(1.946)\end{array}$ & $\begin{array}{c}0.4494 \\
(0.6325)\end{array}$ & $\begin{array}{c}0.3686 \\
(0.5273)\end{array}$ & $\begin{array}{l}0.0620 \\
0.0918\end{array}$ \\
\hline Constant & $\begin{array}{c}-18.31 * * * \\
(3.477)\end{array}$ & $\begin{array}{c}-5.9728 * * * \\
(1.1303) \\
\end{array}$ & $\begin{array}{c}-5.0567 * * * \\
(0.9601)\end{array}$ & $\begin{array}{c}-0.8639 * * * * \\
(0.1640)\end{array}$ \\
\hline
\end{tabular}

(\#) $\mathrm{dF} / \mathrm{dx}$ is for discrete change of dummy variable from 0 to 1.

Robust standard errors in parentheses.

$* * * \mathrm{p}<0.01, * * \mathrm{p}<0.05, * \mathrm{p}<0.1$.

\section{Notes}

Note 1. The informal microfinance sector is largely made up of Susu collectors and the term Susu refers to an informal means by which Ghanaians securely save and access their own money, and might also gain limited access to credit from the Susu collectors.

Note 2. GHAMFIN was established in the year 1998 with the aid of the World Bank to regulate and the keep the database of MFI's in Ghana. In addition to this, Gallardo et al. (2005) lists the activities of GHAMFIN as the microfinance institutional body undertaking policy advocacy and representation, accessing resources for and implementing institutional and staff capacity building programs, and offering a platform for the dissemination and exchange of best practices in microfinance.

Note 3. Sinapi Aba Trust is one of the MFIs in Ghana that provides microfinance services to entrepreneurs in small and micro enterprises with the objective of improving their business and enhancing income generation opportunities in order to alleviate poverty, improve their standard of living, and consequently positively transform their lives.

Note 4. There are yet unpublished studies that use the same approach in Malawi.

Note 5. For a detailed discussion of this literature see Carreira et al. (2010).

Note 6. The survey defines small enterprises as those with 5-19 employees, medium enterprises as those with 20-99 employees and large enterprises as those with 100 and more employees.

Note 7. Since the paper distinguishes unconstrained enterprises from constrained enterprises by the access to finance question, enterprises that have received credit from banks only and not MFIs are excluded in order to specifically analyze the impact that the MFI sector has had and not the finance sector in general.

\section{Copyrights}

Copyright for this article is retained by the author(s), with first publication rights granted to the journal.

This is an open-access article distributed under the terms and conditions of the Creative Commons Attribution license (http://creativecommons.org/licenses/by/3.0/). 